\title{
Research on the training mode of applied innovative talents in logistics management based on "LRCI"
}

\author{
Chang jie ${ }^{1, a}$, fu honghua ${ }^{2, b}$, zhao yuanyuan ${ }^{3, c}$ \\ ${ }^{a}$ jinan 250104, shandong yingcai college
}

Keywords: innovative talent LRCI talent training mode

\begin{abstract}
China's economy is in the transformation of the mode of development, optimizing the economic structure, transform growth research period, new technology, new ideas to guide logistics transformation and upgrading of industrial structure, promoting the logistics demand change, the logistics of logistics professional knowledge, ability and overall quality etc. Put forward the update, higher and more comprehensive requirements. Therefore, centering on the goal of personnel training and oriented by "demand training", we construct a scientific and reasonable innovative personnel training mode for the application of logistics management, and propose an applied innovative personnel training mode for logistics management specialty based on "learning (L) -- research (R) -- competition (C) -- innovation (I)" under the collaboration of the school, enterprise, government and institute.
\end{abstract}

\section{Applied innovative talents of logistics management become urgently needed talents in society}

In recent years, the change of industrial pattern in the world and the development of e-commerce have led to the rapid development of the logistics industry. The total amount of social logistics is constantly increasing. The logistics industry has become an important industry and national economic growth point in the 21st century, and has a broad prospect of development. With the continuous development of information technology and the advent of the era of big data, the formation of the "big logistics" system is effectively promoted, and the huge transformation of the logistics industry is realized [1].

New development situation and opportunity brought higher challenge to supply logistics talents, put forward the more strict requirements, in the current university logistics management professional education and talent cultivation in the process, must grasp the new trend of development of the industry, grasp the opportunities brought about by the emerging technology for higher education, actively respond to challenges at the same time, adjust the relative between the cultivation of thinking and way, train can meet the demand of society and the enterprise logistics management applied creative talents.

\section{Research contents on the training mode of applied innovative talents in logistics management based on "LRCI"}

Demand oriented Education (Outcome - -based Education, referred to as "OBE, also called results oriented Education, ability oriented Education or goal oriented Education), the core idea is the teaching design and teaching goal is to make students through Education process to achieve the desired Learning outcomes (Learning outcomes), pay attention to the analysis to the output of 
students Learning, the Education structure of the reverse design of students and relevant evaluation system. Therefore, we design the research content based on the theoretical basis of OBE.

(I)research on the training objectives and specifications of applied innovative talents in logistics management

According to education reverse design principle, teaching design starts from "demand". Through the analysis of logistics personnel demand, we understand the logistics post demand and capacity requirements, and draw on the requirements of international engineering management ability to form the capacity system required by the application of innovative talents in logistics management. Based on this, we propose the training objectives and specifications of applied innovative talents in logistics management that meet the social needs.

(II)construction of teaching content and curriculum system based on "LRCI"

In order to achieve the goal of cultivating innovative talents in logistics management and the requirements of training specifications, the course system of "platform + module" is constructed on the teaching content based on "learning (L) -- research (R) -- competition (C) -- innovation (I)". Design public basic courses, subject basic courses, professional basic courses, professional skills course modules, innovative education course modules, research tools and methods course modules, and professional elective courses. Through interdisciplinary and course integration, the advanced and practical teaching contents and course system are formed.

(III)design of practical teaching system based on "LRCI"

To professional skills applied ability training as the guide, use two on and off campus practice teaching platform, make full use of the industry, the education resources of the enterprise, the predominantly classroom knowledge education environment and enterprise management combined with the actual environment, the competition projects and project, the enterprise practice for teaching and scientific research into teaching activities, the design of basic experiment, comprehensive design experiment and the innovation research experiment, improve the application ability of students, cultivate the students' innovation ability, the design is based on "learning research (R) (L) - (C) (I) - innovation - competition" practice teaching system.

(IV)construct the "LRCI" innovation and entrepreneurship education engineering practice platform Integrating all kinds of project resources, education engineering practice platform for university students' innovation and entrepreneurship is built with the training program for university students' innovation and entrepreneurship as the core, the discipline professional skill competition and social practice as the expansion. Through school, provincial and national level 3 project management system, organize students to take an active part in all kinds of professional skills competition, social practice, career design, entrepreneurship education activities, academic lectures and other knowledge competition, focus on cultivating students' ability of self knowledge, application knowledge comprehensive design ability, organization and management capacity, access to scientific data and data analysis capability and application ability, character, etc, for the development of students' innovative thinking and innovative ability. Based on this, the education engineering practice platform for the training of applied innovative talents in logistics management of "learning (L) -- research (R) -- competition (C) -- innovation (I)" was constructed.

(V)establish the "LRCI" talent training mode

Based on logistics management professional practical and applied outstanding characteristics, with the help of private colleges of flexible mechanism, the social resources integration capability and innovation spirit, innovation put forward synergy of schools, enterprises, government, based on "learning research (R) (L) - (C) (I) - innovation - competition" logistics management professional applied innovative talents training mode, adopt the sectional training mode, improve the ability of 
students.

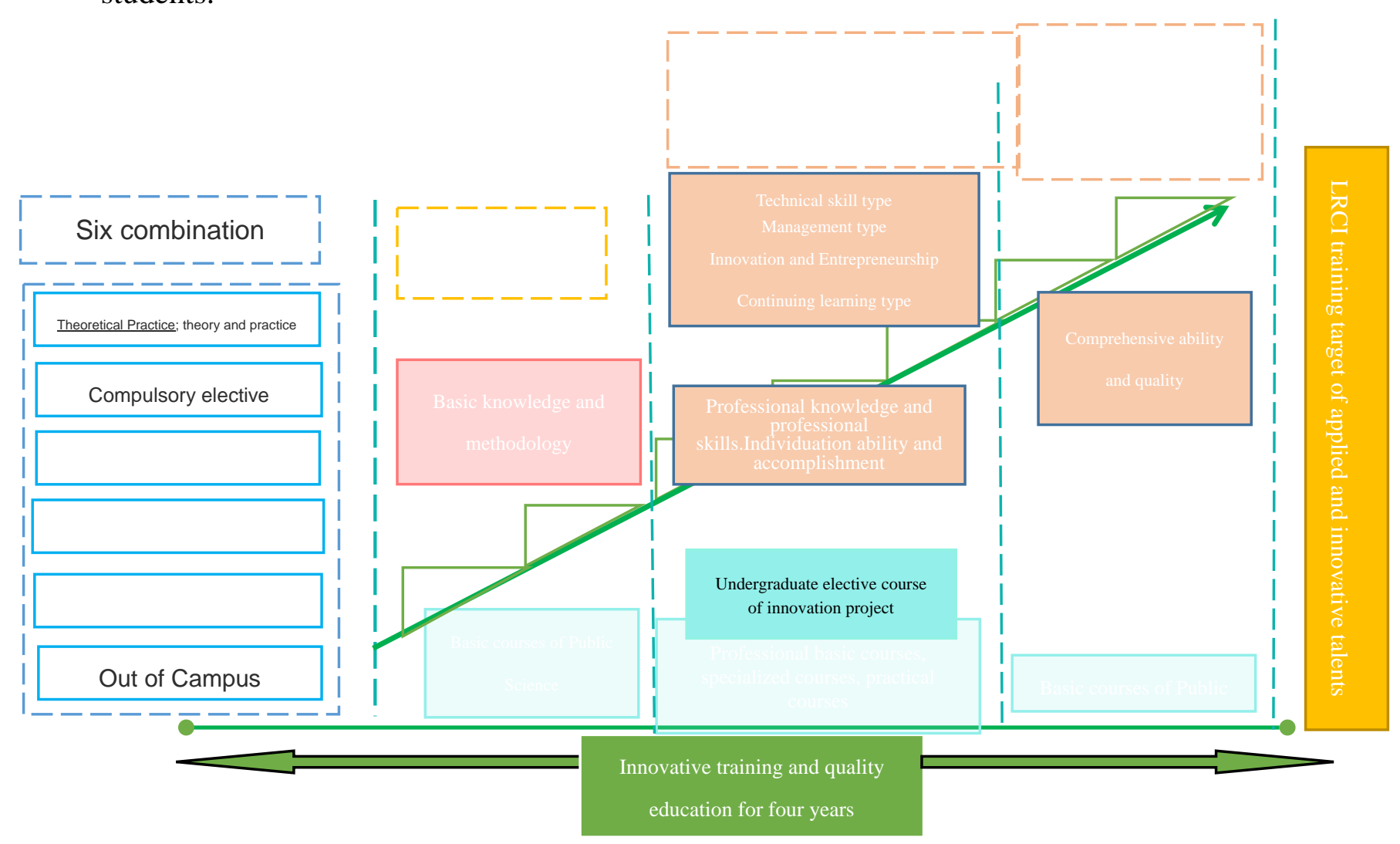

Figure 1 building the "LRCI" talent training mode

\section{Research innovation points}

Firstly, it adopts OBE theory to define the training path for talents in logistics management. Guided by market demand, determine the logistics management major innovative talents training target, from the curriculum system construction, practice teaching system construction, innovation, entrepreneurship education system, the evaluation system, construction of teachers team building perfect logistics management innovative talent training content, especially under the cooperative education mechanism and enterprise cooperation, to demand as the guidance, in order to better meet market demand.

Secondly, on the basis of long-term exploration and practice, the unique flexible mechanism, social resources integration ability and entrepreneurial spirit of our university are fully utilized to create an innovative talent cultivation model based on "LRCI".

Thirdly, a closed-loop talent cultivation quality assessment mechanism is formed [8]. Starting from the students' vocational evaluation, establish archives for students school and enterprise cooperation mechanism, timely feedback of students' information, to understand the quality of talent training, the teaching content and practice ability teaching contents and teaching effect feedback, timely find the problems existing in the talents training, and timely solve, help to improve the quality of personnel training.

\section{References}

[1] zhang lei, yan zhiqiang. Research on the training mode of applied innovative talents in guangxi logistics management specialty from the perspective of employment [J]. China market,2014(18):145-147. 
[2] long huijun, jiang taotao, CAI jianfei. The integrated two-sided cultivation model of applied innovative talents in logistics management specialty [J]. Logistics engineering and management,2014,36(06):158-160+163.

[3] cao xiyu, Yin bin, he bing. Research on the training mode of applied talents in logistics management [J]. Cooperative economy and technology,2016(14):138-139.

[4] zhang min, wu yingping, luo jing. Innovation and practice of the training mode of applied talents in logistics management -- a case study of huizhou university [J]. Logistics technology,2012,35(12):57-60.

[5] zhang xiaoxue. Investigation and analysis of the training mode of logistics management talents in application-oriented universities -- based on the perspective of student satisfaction [J]. Journal of heihe studies,2017(01):20-22.

[6] $\mathrm{xu}$ qin. Exploration and practice of applied innovative talent training mode in logistics management major of applied university [J]. Value engineering,2016,35(36):165-167.

[7] zhong min. Exploration of the cultivation mode of applied logistics management talents based on the idea of supply chain management [J]. Logistics technology,2012,35(08):104-107. 